\title{
EFFICIENCY OF VEGETATIVE PROPAGATION OF CAJÁ-DE-JABUTI UNDER CONCENTRATIONS OF INDOLEBUTYRIC ACID AND GRAFTING METHODS ${ }^{1}$
}

\author{
DHEIMY DA SILVA NOVELLI² ${ }^{2}$, GABRIELA DA SILVA TAMWING ${ }^{3}$, SEBASTIÃO ELVIRO DE ARAÚJO NETO ${ }^{3}$, \\ LUIS GUSTAVO DE SOUZA E SOUZA ${ }^{3 *}$, NILCILÉIA MENDES DA SILVA ${ }^{3}$
}

\begin{abstract}
The objectives of the tests were to evaluate concentrations of indolebutyric acid (IBA) combined with different types of cuttings and grafting methods on the vegetative propagation of cajazeira-dejabuti (S. testudinis). The experiment with stem cuttings was conducted in a greenhouse with an intermittent misting system. The experimental design was completely randomized in a $5 \times 6$ factorial arrangement consisting of five cutting types: apical, medial, basal, stratified, and tanchan, and six IBA concentrations: 0 , $1,000,2,000,3,000,4,000$, and $5,000 \mathrm{mg} \mathrm{kg}^{-1}$, with four replications of ten cuttings. The experiment with the root cuttings followed a randomized block design composed of six IBA concentrations $(0,1,000,2,000,3,000$, 4,000 , and 5,000 $\mathrm{mg} \mathrm{kg}^{-1}$ ) with four replications, evaluating after 120 days the percentages of live, sprouted, rooted, and calloused cuttings, and the number and dry mass of roots and sprouts. Five grafting methods (chip budding, shield budding, cleft grafting, wedge grafting, and splice grafting) were tested by evaluating the graft success and sprouting percentages at 30 and 60 days after grafting, respectively. Statistical analyses were performed using the Kruskal-Wallis non-parametric test. The IBA concentrations of 0, 2,000, 3,000, and $5,000 \mathrm{mg} \mathrm{kg}^{-1}$ increased the number of sprouts in tanchan cuttings. The tanchan cuttings showed the highest survival and percentage of sprouts regardless of the IBA concentration. The IBA concentration of $2,200 \mathrm{mg} \mathrm{kg}^{-1}$ promotes higher rooting rates in root cuttings. Splice grafting provides higher graft success and sprouting rates.
\end{abstract}

Keywords: Spondias testudinis. Asexual propagation. Rooting. Cutting. IBA.

\section{EFICIÊNCIA DA PROPAGAÇÃO VEGETATIVA DE CAJÁ-DE-JABUTI SOB DOSES DE ÁCIDO INDOLBUTÍRICO E MÉTODOS DE ENXERTIA}

\begin{abstract}
RESUMO - Os objetivos dos ensaios foram avaliar doses de ácido indolbutírico (AIB) combinadas com tipos de estacas, e testar métodos de enxertia para a propagação vegetativa de cajazeira-de-jabuti. O experimento com estacas aéreas foi realizado em casa de vegetação, com nebulização intermitente, sob arranjo do delineamento inteiramente casualizado no esquema fatorial $(5 \times 6)$, sendo cinco tipos de estacas: apicais, medianas, basais, basais estratificadas e tanchão, tratadas com seis doses de AIB: 0, 1.000, 2.000, 3.000, 4.000 e $5.000 \mathrm{mg} \mathrm{kg}^{-1}$, com 4 repetições de 10 estacas cada. $\mathrm{Na}$ estaquia radicular, o delineamento foi o blocos casualizados, composto por seis concentrações de AIB: 0, 1.000, 2.000, 3.000, 4.000 e $5.000 \mathrm{mg} \mathrm{kg}^{-1}$, com quatro repetições, sendo avaliado aos 120 dias, porcentagens de estacas vivas, brotadas, enraizadas, calejadas, números e massas secas de raízes e brotações. Foram testados cinco métodos de enxertia: janela aberta, janela fechada, fenda cheia, fenda dupla e inglês simples, avaliado a porcentagens de pegamento e brotação dos enxertos aos 30 e 60 dias, respectivamente, após a enxertia. As análises estatísticas foram realizadas pelo teste não paramétrico de Kruskal-Wallis. As doses de AIB 0, 2.000, 3.000 e $5.000 \mathrm{mg} \mathrm{kg}^{-1}$ aumentaram o número de brotos nas estacas do tipo tanchão. As estacas tanchão possuem maior capacidade de sobrevivência e porcentagem de brotações, independente da dose de AIB. A concentração de $2.200 \mathrm{mg} \mathrm{kg}^{-1}$ de AIB promove maior enraizamento de estacas radiculares. A enxertia à inglesa simples proporciona maior pegamento $\mathrm{e}$ brotações dos enxertos.
\end{abstract}

Palavras-chave: Spondias testudinis. Propagação assexuada. Enraizamento. Estaquia. AIB.

\footnotetext{
${ }^{*}$ Corresponding author

${ }^{1}$ Received for publication in 04/28/2020; accepted in 03/04/2021.

Paper extracted from doctoral thesis of the first author and research additional.

${ }^{2}$ Instituto Federal de Rondônia, Cacoal, RO, Brazil; dheimy.novelli@ifro.edu.br - ORCID: 0000-0001-5888-9058.

${ }^{3}$ Agrarian Sciences Department, Universidade Federal do Acre, Rio Branco, AC, Brazil; gaby_tamwing@hotmail.com - ORCID: 00000002-4692-7237, selviro2000@yahoo.com.br - ORCID: 0000-0002-1212-4989, gustavo_souza_fj@hotmail.com - ORCID: 0000-00018855-5163, nilcileia-ac@hotmail.com - ORCID: 0000-0002-1484-3717.
} 


\section{INTRODUCTION}

The genus Spondias of the family Anacardiaceae is composed of several fruit species that are widely consumed and marketed in Brazil. In the North and Northeast regions of the country, the species known as cajazeira ( $S$. mombin L.), umbuzeiro ( $S$. tuberosa Arruda), cajaraneira (S. dulcis Parkison), sirigueleira (S. purpurea L.), and the hybrids umbu-cajazeira and umbugueleira (Spondias spp.) stand out due to the agro-industrial potential of their fruits (BASTOS et al. 2014; LIMA FILHO; SANTOS, 2009).
Cajazeira-de-jabuti (Spondias testudinis J. D. Mitch \& D.C. Daly) is a fruit species native to the southwest region of Amazônia with a hypothesized endemic occurrence in the Brazilian state of Acre, not being grown for commercial purposes. Its juicy fruits, with fibrous pulp and bittersweet flavor, are mostly used to produce juices, nectars, and ice creams, being little consumed in natura due to their acidity. Fruit color ranges from yellow to orangebrown when ripe, with an oblong shape, mean length from 3.8 to $6.3 \mathrm{~cm}$, and diameter from 2.3 to $2.7 \mathrm{~cm}$, with prominent lenticels on the surface (Figure 1) (MITCHELL; DALY, 2015).

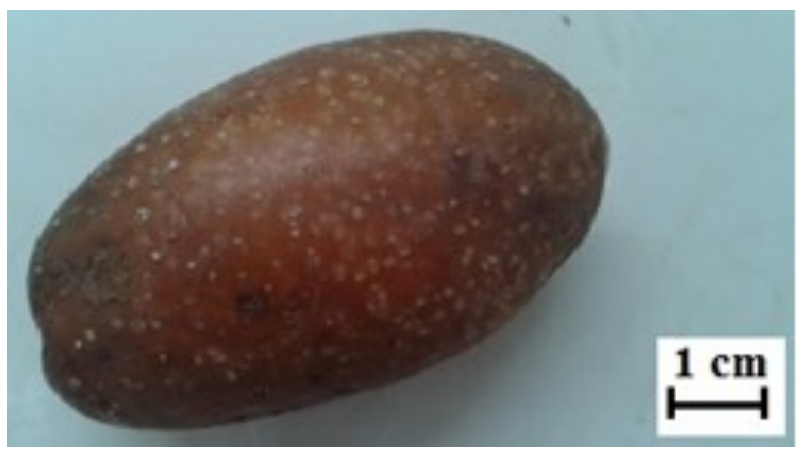

Figure 1. Ripe cajá-de-jabuti (S. testudinis) fruit.

Seed-propagated plants have a long juvenile period during which fruit production does not occur. Therefore, vegetative propagation is an alternative for the commercial use of the species of this genus (DUTRA et al., 2012).

There is still no information in the literature regarding the beginning of fruiting in S. testudinis. However, the data on cajazeira ( $S$. mombin), the most studied species of the genus, are quite promising, such as the reduction from twelve years in the plant cycle of seed-propagated plants to two years in plants propagated by cuttings with $5-10 \mathrm{~cm}$ diameter and $1.20 \mathrm{~m}$ length (FRAIFE FILHO; LEITE; RAMOS, 2016).

Vegetative propagation is common in several fruit species, especially using cuttings and grafting. In species of the genus Spondias, these methods are necessary to establish commercial orchards (DUTRA et al., 2012). However, regarding propagation by cuttings, the adventitious rooting of stem cuttings is highly variable in this genus despite the use of plant growth regulators. This value may be low, as observed in Spondias lutea, with only $2.7 \%$ of rooted cuttings when treated with $5,000 \mathrm{mg} \mathrm{L}^{-1}$ of indolebutyric acid (IBA) (HOLANDA et al., 2012). The authors attribute this low rooting rate to the concentrations of auxin, rooting promoters, hormonal balance, and high concentrations of rooting inhibitors. However, higher rooting rates may occur, such as in $S$. tuberosa $(30.5 \%)$ and $S$. mombin $(43.75 \%)$, by applying the concentration of $6,000 \mathrm{mg} \mathrm{L}^{-1}$ of IBA (RIOS et al., 2012; VÉRAS et al., 2018). The use of root cuttings increases the rooting rates, such as in $S$. mombin, which resulted in $55 \%$ of rooted cuttings in the absence of the exogenous auxin and $77.5 \%$ with the application of $5,000 \mathrm{mg} \mathrm{L}^{-1}$ of IBA (NOVELLI et al., 2019). The authors attributed this positive result to the concentration of rooting cofactors, with the accumulation of carbohydrates and endogenous auxins in the roots.

Grafting is another viable propagation technique for this genus, especially cleft grafting (BASTOS et al., 2014; LIMA FILHO; SANTOS, 2009), due to its efficiency for most fruit species that are propagated by this method (GÓES et al., 2016). In addition to reducing the juvenile phase or homogenizing commercial orchards, grafting is justified by the possibility of adapting the rootstock to the environment, providing resistance to phytopathogens, tolerance to water stress, and early production (LIMA FILHO; SANTOS, 2009; SOUZA et al., 2012; WARSCHEFSKY et al., 2016).

Therefore, this study aimed to evaluate concentrations of indolebutyric acid (IBA) combined with different types of cuttings and grafting methods on the vegetative propagation of cajazeira-de-jabuti (S. testudinis).

\section{MATERIAL AND METHODS}

The experiments were conducted at the 
Seridó Ecological Site in the municipality of Rio Branco - AC, located at the coordinates $9^{\circ} 53^{\prime} 16^{\prime \prime} \mathrm{S}$ and $67^{\circ} 49^{\prime} 11^{\prime}, \mathrm{W}$, with an elevation of $170 \mathrm{~m}$.

The climate is characteristic of the Amazon region, with a mean annual temperature of $24.5^{\circ} \mathrm{C}$, a maximum temperature of $32{ }^{\circ} \mathrm{C}$, and high annual rainfall rates varying from $1,600 \mathrm{~mm}$ to $2,750 \mathrm{~mm}$, with a dry and a rainy season (ACRE, 2010).

Two types of experiments were conducted in a greenhouse covered with a $100-\mu \mathrm{m}$ thick plastic film over a $50 \%$ shade cloth meant to mitigate solar radiation, with the laterals protected by an anti-aphid screen. Irrigation occurred with a timer-controlled intermittent misting system adjusted to irrigate for two minutes with 40-minute intervals. Relative humidity and temperature were monitored with a digital thermo-hygrometer, recording a mean temperature of $26.4{ }^{\circ} \mathrm{C}$ and a mean relative air humidity of $72.2 \%$.

The stem cutting experiments were installed at the end of July 2015 using cuttings collected from plants located in the Zoobotanical Park of the Federal University of Acre (UFAC). The stock plants used were healthy, mature plants in the vegetative stage with approximately 15 years of age.

Five types of cuttings were used: tanchan (tanchão) (60 cm length and a mean diameter of $35.07 \mathrm{~mm} \pm 11.21 \mathrm{~mm})$, basal and stratified $(20 \mathrm{~cm}$ length and a mean diameter of $13.58 \mathrm{~mm} \pm$ $3.49 \mathrm{~mm})$, medial $(15 \mathrm{~cm}$ length and a mean diameter of $7.26 \mathrm{~mm} \pm 1.09 \mathrm{~mm})$, and apical $(12 \mathrm{~cm}$ length and a mean diameter of $5.27 \mathrm{~mm} \pm 0.67 \mathrm{~mm}$ ). The stratified cuttings were horizontally put in the ground and covered with a moistened straw material, where they remained for 30 days, after which they were put in plastic tubes containing vermiculite, as well as the remaining cuttings.

The experimental design was completely randomized, in a $5 \times 6$ factorial arrangement consisting of five types of stem cuttings and six IBA concentrations $(0,1,000,2,000,3,000,4,000$, and $5,000 \mathrm{mg} \mathrm{kg}^{-1}$ of auxin in inert talc), with four replications and ten cuttings per plot.

Plastic tubes with a volume of $125 \mathrm{~cm}^{3}$ were distributed on workbenches covered with a wire mesh meant to hold the tubes, which were filled with a sand substrate.

To root cutting experiment was set up with cuttings collected from two-year-old stock plants and standardized with a $15 \mathrm{~cm}$ length and a diameter of $1.4 \pm 0.2 \mathrm{~cm}$. The containers used were plastic bags with $900 \mathrm{~cm}^{3}$ of a substrate based on soil (33\%), organic compost $(30 \%)$, and leaf litter as a conditioner $(30 \%)$.

The cuttings were manually collected using a hoe and pruning shears, in a process similar to archaeological sampling, by removing the soil close to the roots, which were slowly pulled out of the ground so as not to suffer mechanical damage.

The experimental design of the root cutting experiment was in randomized blocks, with six treatments consisting of the IBA concentrations used in the previous experiment $(0,1,000,2,000,3,000$, 4,000 , and $5,000 \mathrm{mg} \mathrm{kg}^{-1}$ of auxin in inert talc), with four replications and ten cuttings per plot.

In both experiments, the cuttings had their bases cut on a bevel, immersed in water up to $2 / 3$ of their lengths, and treated with IBA $(>99.0 \%)$ mixed with talc. The root cuttings were individually put in $300 \mathrm{~cm}^{3}$ plastic cups.

After 120 days, the percentage of live cuttings, sprouted cuttings, callused cuttings, rooted cuttings, number of roots, root dry matter (RDM), and sprout dry matter (SDM) were evaluated. For the dry matter evaluations, the roots and sprouts were removed from the cuttings using pruning shears, stored in identified paper bags, taken to a forced-air oven at $70{ }^{\circ} \mathrm{C}$, and kept until reaching constant weight, after which the material was weighed with a precision balance.

The grafting experiment was set up in November 2015. The plants used as rootstocks were obtained by sowing the $S$. testudinis seeds on sand. Germination was monitored for six months after sowing. The selected seedlings were transplanted to plastic bags $(18.0 \mathrm{~cm} \times 25.0 \mathrm{~cm} \times 0.15 \mu)$ containing a substrate composed of soil + organic compost + carbonized rice husk at a ratio of $1: 1: 1$, adding $1.5 \mathrm{~kg}$ of thermophosphate and $1 \mathrm{~kg}$ of lime for every $1,000 \mathrm{~L}$ of the substrate. The phytosanitary treatment of the substrate consisted of heating on an iron plate over a wood-fired oven. The plants were kept in the greenhouse until 100 plants reached an $8 \mathrm{~mm}$ $( \pm 2 \mathrm{~mm})$ diameter, after which the grafting process was performed.

The following treatments were tested: a) splice grafting; b) cleft grafting; c) wedge grafting; d) chip budding, and e) shield budding. The experimental design was completely randomized, with five treatments and four replications, with five plants per plot.

The variables evaluated in the grafting experiment were the graft success and the sprouting percentages, obtained at 30 and 60 days after grafting, respectively. The evaluations were performed based on the visual aspect of the grafts, considering as established and alive the ones that showed a green color.

The statistical analyses performed were the presence of outliers by Grubbs' Test, normality of residues by the Shapiro-Wilk test, and homogeneity of variances by Bartlett's test. Since the data did not meet the assumptions of the analysis of variance, the non-parametric test of Kruskal-Wallis or Friedman was applied to all variables. In the root cutting experiment, the live and rooted cuttings met the assumptions and, therefore, were subjected to analysis of variance by the F-test, followed by regression analysis. 


\section{RESULTS AND DISCUSSION}

The tanchan cuttings showed the highest percentages of live $(60.8 \%$ to $100.0 \%)$ and sprouted cuttings $(50.5 \%$ to $75.0 \%)$, regardless of the IBA concentration used (Table 1). These cuttings also showed the highest number of sprouts ( 0.88 to 2.38 ) at the IBA concentrations of $0,2,000,3,000,4,000$, and 5,000 mg kg-1 (Table 2). The larger reserve contents in these cuttings are responsible for their higher survival and sprouting rates (FACHINELLO; HOFFMANN; NACHTIGAL, 2013).

Table 1. Live cuttings and sprouted cuttings, in S. testudinis cuttings treated with indolebutyric acid.

\begin{tabular}{|c|c|c|c|c|c|c|}
\hline \multirow{3}{*}{ Type of cutting } & \multicolumn{6}{|c|}{ IBA concentration $\left(\mathrm{mg} \mathrm{kg}^{-1}\right)$} \\
\hline & \multicolumn{6}{|c|}{ Live cuttings $(\%)$} \\
\hline & 0 & 1,000 & 2,000 & 3,000 & 4,000 & 5,000 \\
\hline Apical & $0.00 \mathrm{Aa}$ & $0.00 \mathrm{Aa}$ & $0.00 \mathrm{Aa}$ & $0.00 \mathrm{Aa}$ & $0.00 \mathrm{Aa}$ & $0.00 \mathrm{Aa}$ \\
\hline Medial & $0.00 \mathrm{Aa}$ & $2.78 \mathrm{Aa}$ & $0.00 \mathrm{Aa}$ & $0.00 \mathrm{Aa}$ & $0.00 \mathrm{Aa}$ & $0.00 \mathrm{Aa}$ \\
\hline Basal & $0.00 \mathrm{Aa}$ & $0.00 \mathrm{Aa}$ & $2.78 \mathrm{Aa}$ & $0.00 \mathrm{Aa}$ & $0.00 \mathrm{Aa}$ & $0.00 \mathrm{Aa}$ \\
\hline Tanchan & $87.50 \mathrm{Ab}$ & $87.50 \mathrm{Ab}$ & $87.50 \mathrm{Ab}$ & $62.50 \mathrm{Ab}$ & $60.80 \mathrm{Ab}$ & $100.00 \mathrm{Ab}$ \\
\hline \multirow[t]{2}{*}{ Stratification } & $0.00 \mathrm{Aa}$ & $0.00 \mathrm{Aa}$ & $0.00 \mathrm{Aa}$ & $0.00 \mathrm{Aa}$ & $0.00 \mathrm{Aa}$ & $0.00 \mathrm{Aa}$ \\
\hline & \multicolumn{6}{|c|}{ Sprouted $(\%)$} \\
\hline Apical & $0.00 \mathrm{Aa}$ & $0.00 \mathrm{Aa}$ & $0.00 \mathrm{Aa}$ & $0.00 \mathrm{Aa}$ & $0.00 \mathrm{Aa}$ & $0.00 \mathrm{Aa}$ \\
\hline Medial & $0.00 \mathrm{Aa}$ & $2.75 \mathrm{Aa}$ & $0.00 \mathrm{Aa}$ & $0.00 \mathrm{Aa}$ & $0.00 \mathrm{Aa}$ & $0.00 \mathrm{Aa}$ \\
\hline Basal & $0.00 \mathrm{Aa}$ & $0.00 \mathrm{Aa}$ & $2.75 \mathrm{Aa}$ & $0.00 \mathrm{Aa}$ & $0.00 \mathrm{Aa}$ & $0.00 \mathrm{Aa}$ \\
\hline Tanchan & $73.00 \mathrm{Ab}$ & $54.00 \mathrm{Ab}$ & $74.70 \mathrm{Ab}$ & $52.00 \mathrm{Ab}$ & $50.50 \mathrm{Ab}$ & $75.00 \mathrm{Ab}$ \\
\hline Stratification & $0.00 \mathrm{Aa}$ & $0.00 \mathrm{Aa}$ & $0.00 \mathrm{Aa}$ & $0.00 \mathrm{Aa}$ & $0.00 \mathrm{Aa}$ & $0.00 \mathrm{Aa}$ \\
\hline
\end{tabular}

Means followed by different lowercase letters in the columns and uppercase letters in the rows differ from each other by the Kruskal-Wallis non-parametric test $(\mathrm{P}<0.05)$.

Table 2. Number of sprouts and percentage of cuttings with calluses in S. testudinis cuttings treated with com indolebutyric acid.

\begin{tabular}{|c|c|c|c|c|c|c|}
\hline \multirow{3}{*}{ Type of cutting } & \multicolumn{6}{|c|}{ IBA concentration $\left(\mathrm{mg} \mathrm{kg}^{-1}\right)$} \\
\hline & \multicolumn{6}{|c|}{ Number of sprouts $(\%)$} \\
\hline & 0 & 1,000 & 2,000 & 3,000 & 4,000 & 5,000 \\
\hline Apical & $0.00 \mathrm{Aa}$ & $0.00 \mathrm{Aa}$ & $0.00 \mathrm{Aa}$ & $0.00 \mathrm{Aa}$ & $0.00 \mathrm{Aa}$ & $0.00 \mathrm{Aa}$ \\
\hline Medial & $0.00 \mathrm{Aa}$ & $2.75 \mathrm{Aa}$ & $0.00 \mathrm{Aa}$ & $0.00 \mathrm{Aa}$ & $0.00 \mathrm{Aa}$ & $0.00 \mathrm{Aa}$ \\
\hline Basal & $0.00 \mathrm{Aa}$ & $0.00 \mathrm{Aa}$ & $0.03 \mathrm{Aab}$ & $0.00 \mathrm{Aa}$ & $0.00 \mathrm{Aa}$ & $0.00 \mathrm{Aa}$ \\
\hline Tanchan & $1.63 \mathrm{Ab}$ & $1.88 \mathrm{Aa}$ & $2.38 \mathrm{Ab}$ & $1.38 \mathrm{Ab}$ & $0.88 \mathrm{Ab}$ & $2.25 \mathrm{Ab}$ \\
\hline \multirow[t]{2}{*}{ Stratification } & $0.00 \mathrm{Aa}$ & $0.00 \mathrm{Aa}$ & $0.00 \mathrm{Aa}$ & $0.00 \mathrm{Aa}$ & $0.00 \mathrm{Aa}$ & $0.00 \mathrm{Aa}$ \\
\hline & \multicolumn{6}{|c|}{ Percentage of calluses $(\%)$} \\
\hline Apical & $0.00 \mathrm{Aa}$ & $0.00 \mathrm{Aa}$ & $0.00 \mathrm{Aa}$ & $0.00 \mathrm{Aa}$ & $0.00 \mathrm{Aa}$ & $0.00 \mathrm{Aa}$ \\
\hline Medial & $0.00 \mathrm{Aa}$ & $2.75 \mathrm{Aab}$ & $0.00 \mathrm{Aa}$ & $0.00 \mathrm{Aa}$ & $0.00 \mathrm{Aa}$ & $0.00 \mathrm{Aa}$ \\
\hline Basal & $0.00 \mathrm{Aa}$ & $0.00 \mathrm{Aa}$ & $0.00 \mathrm{Aa}$ & $0.00 \mathrm{Aa}$ & $0.00 \mathrm{Aa}$ & $0.00 \mathrm{Aa}$ \\
\hline Tanchan & $87.50 \mathrm{Ab}$ & $86.80 \mathrm{Ab}$ & $88.20 \mathrm{Ab}$ & $62.50 \mathrm{Ab}$ & $50.00 \mathrm{Ab}$ & $100.00 \mathrm{Ab}$ \\
\hline Stratification & $0.00 \mathrm{Aa}$ & $0.00 \mathrm{Aa}$ & $0.00 \mathrm{Aa}$ & $0.00 \mathrm{Aa}$ & $0.00 \mathrm{Aa}$ & $0.00 \mathrm{Aa}$ \\
\hline
\end{tabular}

Means followed by different lowercase letters in the columns and uppercase letters in the rows differ from each other by the Kruskal-Wallis non-parametric test $(\mathrm{P}<0.05)$.

Despite the high sprouting rates of the stem cuttings, their rooting capacity is low. Apical cuttings of cajá (Spondias mombin L.) behave very similarly to those of cajá-de-jabuti (S. testudinis), with sprouting rates from $50.0 \%$ to $75.0 \%$ and low rooting $(8.33 \%$ to $25.0 \%)$ at the IBA concentrations of $0,500,1,000,1,500$, and 2,000 $\mathrm{mg} \mathrm{L}^{-1}$ (SOUZA; LIMA, 2005).

Low rooting is common among the species of the genus Spondias (BASTOS et al., 2014; ROCHA et al., 2019), and the application of auxin has not increased the rooting percentages, which correspond to only $2.7 \%$ in S. lutea (HOLANDA et al., 2012), $13.5 \%$ in umbu-cajazeira (Spondias spp.) (BASTOS et al., 2014), and $30.5 \%$ in $S$. tuberosa (RIOS et al., 2012).

The tanchan cuttings showed the highest percentage of calluses $(50.0 \%$ to $100.0 \%)$ at all IBA concentrations (Table 2). However, the plant growth regulator did not significantly affect the rooting rate $(0 \%$ to $25.0 \%)$ and the number of roots (0 to 0.38$)$ (Table 3). The poor response of the cuttings of 
Spondias spp. to IBA application may occur due to the genetic variability and the species, the degree of lignification of the cuttings, and the release of phenolic compounds that oxidize tissues (CUNHA, 2013).

The number (Table 2) and dry mass of sprouts (Table 4) were influenced by the types of stem cuttings. Sprout formation before the emission of adventitious roots may be undesirable as these structures drain the reserves contained in the cuttings to the detriment of rooting. Therefore, if root formation does not occur, there will be water loss due to the increase of the transpiration rate and, consequently, death of the sprouts along with the cuttings due to reserve depletion (SOUZA; LIMA, 2005). On the other hand, the presence of sprouts in the cuttings may favor rooting as the new leaves, given enough time, assist in the synthesis and mobilization of auxins (MOUBAYIDIN et al., 2010; VÉRAS et al., 2018).

Since the survival rates in the tanchan cuttings were not significant, maybe these cuttings require a longer rooting time (Table 3) as their reserves are greater and may last longer.

Table 3. Rooted cuttings and number of roots in S. testudinis cuttings treated with indolebutyric acid (IBA).

\begin{tabular}{ccccccc}
\hline & \multicolumn{5}{c}{ Rooted cuttings (\%) } \\
\hline \multirow{2}{*}{ Type of cutting } & 0 & \multicolumn{7}{c}{ IBA concentration $\left(\mathrm{mg} \mathrm{kg}^{-1}\right)$} \\
\cline { 2 - 6 } & 0.000 & 2,000 & 3,000 & 4,000 & 5,000 \\
\hline Apical & $0.00 \mathrm{Aa}$ & $0.00 \mathrm{Aa}$ & $0.00 \mathrm{Aa}$ & $0.00 \mathrm{Aa}$ & $0.00 \mathrm{Aa}$ & $0.00 \mathrm{Aa}$ \\
Medial & $0.00 \mathrm{Aa}$ & $0.00 \mathrm{Aa}$ & $0.00 \mathrm{Aa}$ & $0.00 \mathrm{Aa}$ & $0.00 \mathrm{Aa}$ & $0.00 \mathrm{Aa}$ \\
Basal & $0.00 \mathrm{Aa}$ & $0.00 \mathrm{Aa}$ & $0.00 \mathrm{Aa}$ & $0.00 \mathrm{Aa}$ & $0.00 \mathrm{Aa}$ & $0.00 \mathrm{Aa}$ \\
Tanchan & $0.00 \mathrm{Aa}$ & $12.50 \mathrm{Aa}$ & $0.00 \mathrm{Aa}$ & $25.00 \mathrm{Aa}$ & $0.00 \mathrm{Aa}$ & $24.30 \mathrm{Aa}$ \\
Stratification & $0.00 \mathrm{Aa}$ & $0.00 \mathrm{Aa}$ & $0.00 \mathrm{Aa}$ & $0.00 \mathrm{Aa}$ & $0.00 \mathrm{Aa}$ & $0.00 \mathrm{Aa}$ \\
\hline & & Number of roots & & $0.00 \mathrm{Aa}$ \\
Apical & $0.00 \mathrm{Aa}$ & $0.00 \mathrm{Aa}$ & $0.00 \mathrm{Aa}$ & $0.00 \mathrm{Aa}$ & $0.00 \mathrm{Aa}$ & $0.00 \mathrm{Aa}$ \\
Medial & $0.00 \mathrm{Aa}$ & $0.00 \mathrm{Aa}$ & $0.00 \mathrm{Aa}$ & $0.00 \mathrm{Aa}$ & $0.00 \mathrm{Aa}$ & $0.00 \mathrm{Aa}$ \\
Basal & $0.00 \mathrm{Aa}$ & $0.00 \mathrm{Aa}$ & $0.00 \mathrm{Aa}$ & $0.00 \mathrm{Aa}$ & $0.00 \mathrm{Aa}$ & $0.38 \mathrm{Aa}$ \\
Tanchan & $0.00 \mathrm{Aa}$ & $0.13 \mathrm{Aa}$ & $0.00 \mathrm{Aa}$ & $0.63 \mathrm{Aa}$ & $0.00 \mathrm{Aa}$ & $0.00 \mathrm{Aa}$ \\
Stratification & $0.00 \mathrm{Aa}$ & $0.00 \mathrm{Aa}$ & $0.00 \mathrm{Aa}$ & $0.00 \mathrm{Aa}$ & $0.00 \mathrm{Aa}$ & 0.000
\end{tabular}

Means followed by different lowercase letters in the columns and uppercase letters in the rows differ from each other by the Kruskal-Wallis non-parametric test $(\mathrm{P}<0.05)$.

Table 4. Longest root length (LRL), root dry matter (RDM), and sprout dry matter (SDM) of S. testudinis cuttings treated with indolebutyric acid (IBA).

\begin{tabular}{|c|c|c|c|c|c|c|}
\hline \multirow{3}{*}{ Type of cutting } & \multicolumn{6}{|c|}{ LRL (cm) } \\
\hline & \multicolumn{6}{|c|}{ IBA concentration $\left(\mathrm{mg} \mathrm{kg}^{-1}\right)$} \\
\hline & 0 & 1,000 & 2,000 & 3,000 & 4,000 & 5,000 \\
\hline Apical & $0.00 \mathrm{Aa}$ & $0.00 \mathrm{Aa}$ & $0.00 \mathrm{Aa}$ & $0.00 \mathrm{Aa}$ & $0.00 \mathrm{Aa}$ & $0.00 \mathrm{Aa}$ \\
\hline Medial & $0.00 \mathrm{Aa}$ & $0.00 \mathrm{Aa}$ & $0.00 \mathrm{Aa}$ & $0.00 \mathrm{Aa}$ & $0.00 \mathrm{Aa}$ & $0.00 \mathrm{Aa}$ \\
\hline Basal & $0.00 \mathrm{Aa}$ & $0.00 \mathrm{Aa}$ & $0.00 \mathrm{Aa}$ & $0.00 \mathrm{Aa}$ & $0.00 \mathrm{Aa}$ & $0.00 \mathrm{Aa}$ \\
\hline Tanchan & $0.00 \mathrm{Aa}$ & $3.13 \mathrm{Aa}$ & $0.00 \mathrm{Aa}$ & $9.89 \mathrm{Aa}$ & $0.00 \mathrm{Aa}$ & 4.50 Aa \\
\hline \multirow[t]{2}{*}{ Stratification } & $0.00 \mathrm{Aa}$ & $0.00 \mathrm{Aa}$ & $0.00 \mathrm{Aa}$ & $0.00 \mathrm{Aa}$ & $0.00 \mathrm{Aa}$ & $0.00 \mathrm{Aa}$ \\
\hline & \multicolumn{6}{|c|}{ RDM (g) } \\
\hline Apical & $0.00 \mathrm{Aa}$ & $0.00 \mathrm{Aa}$ & $0.00 \mathrm{Aa}$ & $0.00 \mathrm{Aa}$ & $0.00 \mathrm{Aa}$ & $0.00 \mathrm{Aa}$ \\
\hline Medial & $0.00 \mathrm{Aa}$ & $0.00 \mathrm{Aa}$ & $0.00 \mathrm{Aa}$ & $0.00 \mathrm{Aa}$ & $0.00 \mathrm{Aa}$ & $0.00 \mathrm{Aa}$ \\
\hline Basal & $0.00 \mathrm{Aa}$ & $0.00 \mathrm{Aa}$ & $0.00 \mathrm{Aa}$ & $0.00 \mathrm{Aa}$ & $0.00 \mathrm{Aa}$ & $0.00 \mathrm{Aa}$ \\
\hline Tanchan & $0.00 \mathrm{Aa}$ & $0.13 \mathrm{Aa}$ & $0.00 \mathrm{Aa}$ & $0.46 \mathrm{Aa}$ & $0.00 \mathrm{Aa}$ & $2.03 \mathrm{Aa}$ \\
\hline \multirow[t]{2}{*}{ Stratification } & $0.00 \mathrm{Aa}$ & $0.00 \mathrm{Aa}$ & $0.00 \mathrm{Aa}$ & $0.00 \mathrm{Aa}$ & $0.00 \mathrm{Aa}$ & $0.00 \mathrm{Aa}$ \\
\hline & \multicolumn{6}{|c|}{ SDM (g) } \\
\hline Apical & $0.00 \mathrm{Aa}$ & $0.00 \mathrm{Aa}$ & $0.00 \mathrm{Aa}$ & $0.00 \mathrm{Aa}$ & $0.00 \mathrm{Aa}$ & $0.00 \mathrm{Aa}$ \\
\hline Medial & $0.00 \mathrm{Aa}$ & $0.00 \mathrm{Aa}$ & $0.00 \mathrm{Aa}$ & $0.00 \mathrm{Aa}$ & $0.00 \mathrm{Aa}$ & $0.00 \mathrm{Aa}$ \\
\hline Basal & $0.00 \mathrm{Aa}$ & $0.00 \mathrm{Aa}$ & $0.00 \mathrm{Aa}$ & $0.00 \mathrm{Aa}$ & $0.00 \mathrm{Aa}$ & $0.00 \mathrm{Aa}$ \\
\hline Tanchan & $0.57 \mathrm{Ab}$ & $5.26 \mathrm{Ab}$ & $0.48 \mathrm{Ab}$ & $4.83 \mathrm{Ab}$ & $3.90 \mathrm{Ab}$ & $4.68 \mathrm{Ab}$ \\
\hline Stratification & $0.00 \mathrm{Aa}$ & $0.00 \mathrm{Aa}$ & $0.00 \mathrm{Aa}$ & $0.00 \mathrm{Aa}$ & $0.00 \mathrm{Aa}$ & $0.00 \mathrm{Aa}$ \\
\hline
\end{tabular}

Means followed by different lowercase letters in the columns and uppercase letters in the rows differ from each other by the Kruskal-Wallis non-parametric test $(\mathrm{P}<0.05)$. 
The root cuttings provided the highest rooting $(28.43 \%)$ and survival percentages $(36.65 \%)$ at the IBA concentrations of 2,200 and 2,216.67 mg kg-1, respectively (Figure 2), decreasing above these values. In cajazeira ( $S$. mombin), IBA concentrations higher than $2,000 \mathrm{mg} \mathrm{L}^{-1}$ were also toxic to the plant tissues, causing the mortality of apical stem cuttings (SOUZA; LIMA, 2005). The application of the exogenous auxin did not influence $(p>0.05)$ the number of roots, callus formation, and shoot and root dry matter (Table 5).

Novelli et al. (2019) observed an increase in the rooting rate of $S$. mombin root cuttings varying from $55.0 \%$ in the absence of the exogenous auxin to $77.5 \%$ with the application of $5,000 \mathrm{mg} \mathrm{kg}^{-1}$, while stem cuttings rooted from 0 to $25 \%$ and did not respond to the exogenous auxin. Campagnolo and Pio (2012), evaluating blackberry propagation by stem and root cuttings, observed that the root cuttings provided a rooting rate of $89.3 \%$ and callus formation in $100 \%$ of the cuttings.

As observed in Figure 2, the highest IBA concentrations were inhibitory for the root cuttings with a low rooting percentage $(5 \%)$. There was a $75.2 \%$ reduction in the cuttings treated with 5,000 mg. $\mathrm{kg}^{-1}$ of IBA compared to the remaining concentrations. This result differs from that obtained by Véras et al. (2018) in stem cuttings of umbucajazeira (Spondias sp.), which showed maximum rooting $(43.75 \%)$ at the highest IBA concentration $\left(6,000 \mathrm{mg} \mathrm{L}^{-1}\right)$.

In addition to the hormonal balance, other internal and external factors influence the rooting and survival of cuttings, such as the harvest time (RIOS et al., 2012), genotype, temperature and humidity conditions during the period when the cuttings are kept in the greenhouse (DENAXA et al., 2012, ZANG et al., 2013), and conditioning agents applied to the cuttings (MENDES et al., 2019).

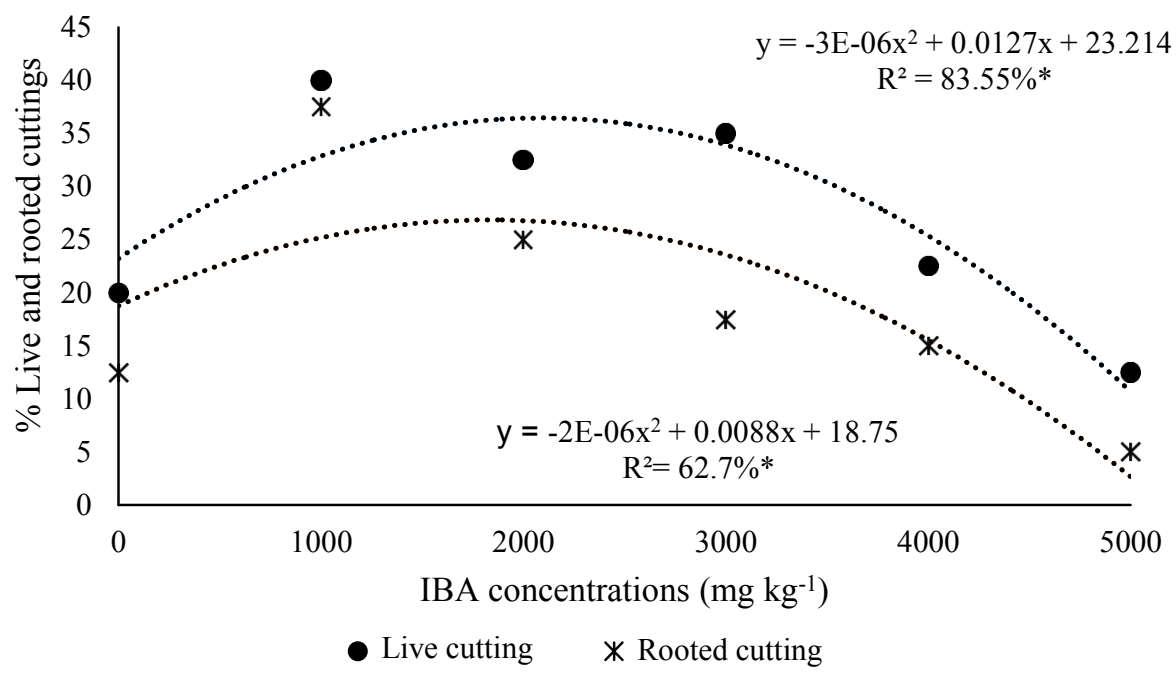

Figure 2. Percentage of live and rooted cuttings at 120 days after the application of different IBA concentrations.

The IBA concentrations did not influence ( $p>0.05)$ the sprouting percentage, which was low, varying from 0 to $7.5 \%$, with sprout emission occurring in only six of the 240 cuttings evaluated
(Table 5). These results differ from the observed in the tanchan cuttings of this same species, which, regardless of IBA application, showed high sprouting rates, varying from 50 to $75 \%$.

Table 5. Number of roots (NR), callused cuttings, sprouted cuttings, and dry mass of roots (RDM) and sprouts (SDM) in stem cuttings of $S$. testudinis treated with indolebutyric acid (IBA).

\begin{tabular}{|c|c|c|c|c|c|}
\hline $\operatorname{IBA}\left(\mathrm{mg} \mathrm{L}^{-1}\right)$ & Number of roots & Callused cuttings (\%) & Sprouted cuttings $(\%)$ & Sprout dry mass $\left(\mathrm{g} \mathrm{plant}^{-1}\right)$ & Root dry mass $\left(\right.$ g plant $\left.^{-1}\right)$ \\
\hline 0 & 2.75 & 7.5 & 5 & 0.41 & 0.023 \\
\hline 1,000 & 7.50 & 2.5 & 7.5 & 0.13 & 0.024 \\
\hline 2,000 & 6.75 & 2.5 & 0 & 0.00 & 0.013 \\
\hline 3,000 & 5.00 & 10.0 & 0 & 0.00 & 0.011 \\
\hline 4,000 & 3.50 & 2.5 & 2.5 & 0.01 & 0.006 \\
\hline 5,000 & 1.25 & 2.5 & 0 & 0.00 & 0.002 \\
\hline
\end{tabular}

There was no statistical difference by the Friedman test at $5 \%$ probability. 
Splice grafting provided the highest graft success and sprouting rates, not differing from wedge grafting (Table 6). Cleft grafting is the most recommended grafting method for the genus Spondias, although low success rates occur, such as in the species cajazeira $(S$. mombin) $(66.7 \%)$ and cajá-manga (S. cytherea) (25\%), respectively (LIMA FILHO; SANTOS, 2009). However, Bastos et al. (2014) observed a success rate of up to $100 \%$ for umbu-cajá (Spondias spp.), stating that graft success in Spondias depends on the combination between scion and rootstock and the type of grafting.

Table 6. Graft success and survival of $S$. testudinis propagated by chip budding, shield budding, cleft grafting, wedge grafting, and splice grafting.

\begin{tabular}{ccc}
\hline Propagation method & Graft success (\%) & Sprouting (\%) \\
\hline Chip budding & $25.0 \mathrm{~b}$ & $0.0 \mathrm{~b}$ \\
Shield budding & $0.0 \mathrm{~b}$ & $0.0 \mathrm{~b}$ \\
Cleft grafting & $25.0 \mathrm{~b}$ & $12.5 \mathrm{~b}$ \\
Wedge grafting & $50.0 \mathrm{ab}$ & $37.5 \mathrm{ab}$ \\
Splice grafting & $100.0 \mathrm{a}$ & $100.0 \mathrm{a}$ \\
\hline
\end{tabular}

Means followed by the same letter do not differ $(\mathrm{p}>0.05)$ by the non-parametric test of Kruskal-Wallis.

The greatest tissue damage caused by the wedge and cleft grafting methods and the low healing capacity may have influenced the lower sprouting rates compared to splice grafting. In pitangueira (Eugenia uniflora L.), a lower graft success rate was observed with the wedge grafting technique (44.2\%) compared to cleft grafting (60\%) due to stem lignification and oxidative injuries, which prevent the healing of incisions (FRANZON et al., 2008).

The high grafting efficiency of the splice grafting method also occurs with umbuzeiro ( $S$. tuberosa), especially in cuttings with smaller diameters $(0.75$ to $1.0 \mathrm{~cm})$, being up to $100 \%$ superior to wedge grafting $(87.5 \%)$. Gomes et al. (2010) attribute this behavior to the greater amount of reserves, which may favor the quick cell dedifferentiation and redifferentiation, with subsequent formation of calluses and vascular connections.

\section{CONCLUSION}

The rooting of stem cuttings is low and is not influenced by the type of cutting and IBA application. The tanchan cuttings showed the highest survival and sprouting rates regardless of IBA application. The IBA dose of 2,200 mg kg-1 promotes higher rooting rates in root cuttings. The survival, rooting, and sprouting rates were low. Splice grafting provides the highest graft success $(100 \%)$ and sprouting rates $(100 \%)$.

\section{ACKNOWLEDGMENTS}

To CAPES, CNPC, and FAPAC for the concession of the scholarships to the authors.

\section{REFERENCES}

ACRE. Secretaria de Estado de Meio Ambiente. Zoneamento Ecológico-Econômico do Acre fase II: recursos naturais: biodiversidade e ambientes do Acre. 2010. Disponível em: <https:// www.amazonia.cnptia.embrapa.br/ publicacoes_estados/Acre/Fase\%202/

Livro_Tematico_ZEE_Recursos_Naturais_Volume 2.pdf $>$. Acesso em: $1 \overline{6}$ mar. $201 \overline{9}$.

BASTOS, L. P. et al. Propagação vegetativa de umbu-cajazeira. Enciclopédia Biosfera, 10: 25082517, 2014.

CAMPAGNOLO, M. A., PIO, R. Enraizamento de estacas caulinares e radiculares de cultivares de amoreira-preta coletadas em diferentes épocas, armazenadas a frio e tratadas com AIB. Ciência Rural, 42: 232-237, 2012.

CUNHA, P. S. C. F. Enraizamento de estacas de Spondias submetidas a doses de ácido Indolbutírico (AIB) e substratos. 2013. $79 \mathrm{f}$. Dissertação (Mestrado em Agronomia: Fitotecnia) Universidade Federal Rural do Semi-Árido, Mossoró, 2013.

DENAXA, N. K. et al. The role of endogenous carbohydrates and seasonal variation in rooting ability of cuttings of an easy and a hard to root olive cultivars (Olea europaea L.). Scientia Horticulturae, 143: 19-28, 2012.

DUTRA, T. R. et al. Ácido indolbutírico e substratos na alporquia de umbuzeiro. Pesquisa Agropecuária Tropical, 42: 424-429, 2012. 
FACHINELLO, J. C.; HOFFMANN, A.; NACHTIGAL, J. C. Propagação de Plantas Frutíferas. 2 ed. Brasília, DF: Embrapa. 2013. 191 p.

FRAIFE FILHO, A. G.; LEITE, J. B. V.; RAMOS, J. V. Cajá. Disponível em: <http://www.ceplac.gov.br/ radar/caja.htm>. Acesso em: 10 out. 2016.

FRANZON, R. C. et al. Propagação de pitangueira através da enxertia de garfagem. Revista Brasileira de Fruticultura, 30: 488-491, 2008.

GÓES, G. B. et al. Métodos de enxertia na produção de mudas de tamarindeiro. Revista Ceres, 63: 853$859,2016$.

GOMES, W. A. et al. Garfagem e diâmetro de portaenxerto na obtenção de mudas de umbuzeiro do acesso laranja. Revista Brasileira de Fruticultura, 32: 952-959, 2010.

HOLANDA, F. S. R. et al. Propagation through cutting technique of species occurring in the lower São Francisco river in Sergipe state with different concentrations of indolebutyric acid. Revista Árvore, 36: 75-82, 2012.

LIMA FILHO, J. M. P.; SANTOS, C. A. F. Avaliação fenotípica e fisiológica de espécies de Spondias tendo como porta-enxerto o umbuzeiro (Spondias tuberosa Cam.). Revista Caatinga, 22: 59 $-63,2009$.

MENDES, N. V. B. et al. Agrochemicals and stem cutting types for plantlet production of Spondias sp. Revista Caatinga, 32: $1104-1110,2019$.

MITCHELL, J. D.; DALlY, D. C. A revision of Spondias L. (Anacardiaceae) in the Neotropics. PhytoKeys, 55: 1-92, 2015

MOUBAYIDIN, L. et al. The rate of cell differentiation controls the Arabidopsis root meristem growth phase. Current Biology, 20: 11381143, 2010.

NOVELLI, D. S. et al. Propagation of yellow mombin by stem and root cuttings treated with indolebutyric acid. Comunicata Scientiae, 10: 448 453, 2019.

RIOS, E. S. et al. Concentrações de ácido indolbutírico, comprimento e época de coleta de estacas, na propagação de umbuzeiro. Revista Caatinga, 25: 52-57, 2012.

ROCHA, G. T. et al. Vegetative propagation of
Spondias tuberosa e Spondias dulcis with the use of immersion in indole acetic acid. Revista Caatinga, 32: 858-866, 2019.

SOUZA, F. X. et al. Comportamento vegetativo e reprodutivo de clones de cajazeira cultivados na Chapada do Apodi, Ceará. Revista Ciências Agronômica, 43: 293-300, 2012.

SOUZA, F. X.; LIMA, R. N. Enraizamento de estacas de diferentes matrizes de cajazeira tratadas com ácido indolbutírico. Revista Ciência Agronômica, 36: 189-194, 2005.

VÉRAS, M. L. M. et al. Uso de reguladores vegetais na propagação via estaquia de umbu-cajazeira. Revista de Ciências Agrárias, 41: 740-748, 2018.

ZANG, W. et al. Effects of temperature, plant growth regulators and substrates and changes in carbohydrate content during bulblet formation by twinscale propagation in Hippeastrum vittatum 'Red lion’. Scientia Horticulturae, 160: 230-237, 2013.

WARSCHEFSKY, E. et al. Rootstocks: Diversity, Domestication and Impacts on Shoot Phenotypes. Trends in Plant Science, 21: 418-437, 2016. 